\title{
Chimeric Antigen Receptor-Engineered T Cells for the Treatment of Metastatic Prostate Cancer
}

\author{
Victoria Hillerdal $^{1} \cdot$ Magnus Essand $^{1}$
}

Published online: 10 April 2015

(c) The Author(s) 2015. This article is published with open access at Springerlink.com

\begin{abstract}
Cancer immunotherapy was selected as the Breakthrough of the Year 2013 by the editors of Science, in part because of the successful treatment of refractory hematological malignancies with adoptive transfer of chimeric antigen receptor (CAR)-engineered T cells. Effective treatment of B cell leukemia may pave the road to future treatment of solid tumors, using similar approaches. The prostate expresses many unique proteins and, since the prostate gland is a dispensable organ, CAR $\mathrm{T}$ cells can potentially be used to target these tissue-specific antigens. However, the location and composition of prostate cancer metastases complicate the task of treating these tumors. It is therefore likely that more sophisticated CAR T cell approaches are going to be required for prostate metastasis than for B cell malignancies. Two main challenges that need to be resolved are how to increase the migration and infiltration of CAR $\mathrm{T}$ cells into prostate cancer bone metastases and how to counteract the immunosuppressive microenvironment found in bone lesions. Inclusion of homing (chemokine) receptors in CAR T cells may improve their recruitment to bone metastases, as may antibody-based combination therapies to normalize the tumor vasculature. Optimal activation of CAR T cells through the introduction of multiple costimulatory domains would help to overcome inhibitory signals from the tumor microenvironment. Likewise, combination therapy with checkpoint
\end{abstract}

Victoria Hillerdal

Victoria.Hillerdal@igp.uu.se

Magnus Essand

magnus.essand@igp.uu.se

1 Science for Life Laboratory, Department of Immunology, Genetics and Pathology, Uppsala University, 75185 Uppsala, Sweden inhibitors that can reduce tumor immunosuppression may help improve efficacy. Other elegant approaches such as induced expression of immune stimulatory cytokines upon target recognition may also help to recruit other effector immune cells to metastatic sites. Although toxicities are difficult to predict in prostate cancer, severe on-target/offtumor toxicities have been observed in clinical trials with use of CAR T cells against hematological malignancies; therefore, the choice of the target antigen is going to be crucial. This review focuses on different means of accomplishing maximal effectiveness of CAR T cell therapy for prostate cancer bone metastases while minimizing side effects and CAR T cell-associated toxicities. CAR T cellbased therapies for prostate cancer have the potential to be a therapy model for other solid tumors.

\section{Adoptive CAR T Cell Therapy}

The use of $\mathrm{T}$ cells to treat solid tumors was initially reported in 1988, when Rosenberg et al. [1] at the National Cancer Institute accomplished complete regressions of tumors in patients with metastatic melanoma by using adoptive therapy with tumor-infiltrating lymphocytes (TILs). Subsequent optimization of the treatment led to an objective response rate of approximately $50 \%$ with adoptive TIL therapy in subsequent trials [2]. This therapy is, however, limited by the feasibility of isolating TILs from resected tumors or biopsy material. So far, it has only been successfully used for malignant melanoma. To overcome this limitation, $\mathrm{T}$ cells can be isolated from the peripheral blood of cancer patients, genetically engineered to recognize a specific tumor-associated antigen, expanded in vitro, and adoptively transferred back to the patient. Specificity of the $\mathrm{T}$ cell response can then be achieved 
either by introducing a new $\mathrm{T}$ cell receptor (TCR) that recognizes a tumor-derived antigen peptide in the context of human leukocyte antigen (HLA) presentation or by introducing a chimeric antigen receptor (CAR) that recognizes a cell surface antigen on tumor cells. Both TCR and CAR therapies have had some success in recent years. The first report of clinical benefit from use of TCR-redirected T cells was published in 2006, also from Rosenberg's laboratory [3]. Since then, TCR-engineered T cells have been shown to produce durable responses in metastatic melanoma and renal cell carcinoma patients [4, 5]. While TCR-redirected $\mathrm{T}$ cells have the great advantage of being able to target any antigen, including intracellular proteins, various obstacles can limit their utility, including restriction to a particular HLA subtype, down-regulation of HLA expression on tumors as a means of escaping immunity, mispairing of the introduced TCR $\alpha$ and $\beta$ chains with the endogenous TCR chains, low physiological affinities of natural TCRs, and toxicities associated with processing of identical peptides derived from proteins other than the target. Many of these obstacles, including HLA dependency and problems with low affinity, can be overcome by the use of CAR T cells (see Box 1) [6].

A CAR typically comprises an extracellular single-chain variable fragment ( $\mathrm{scFv}$ ) of an antibody for target recognition, a hinge region to provide flexibility for the $\mathrm{scFv}$, a transmembrane region, and an intracellular signaling region. CARs are often referred to as first, second, or third generation, depending on their signaling moieties (see Fig. 1). First-generation CARs contain only the CD3- $\zeta$ chain, while second-generation CARs contain CD3- $\zeta$ and a domain from a costimulatory molecule-typically from CD28, 4-1BB, CD27, ICOS, or OX40-which augments the effect of CD3- $\zeta$ signaling. Third-generation CARs contain $\mathrm{CD} 3-\zeta$ and two costimulatory molecule domains. The center at Baylor College of Medicine performed sideby-side comparison of first- and second-generation CARs in patients with $\mathrm{B}$ cell lymphoma and found that CD28 costimulation was associated with enhanced persistence and survival of CAR-modified T cells [7]. Possibly even stronger activation can be obtained with third-generation CAR T cells [8-15], as they are capable of high proliferative responses in vivo, which may facilitate clinical responses. However, third-generation CAR T cells produce large amounts of cytokines, which could be associated with toxicity. To mediate efficient expression of CAR genes into $\mathrm{T}$ cells, different genetic platforms have been used to ensure integration of the transgene into the $\mathrm{T}$ cell genome and to ensure that the construct directs long-lasting expression of the CAR (see Box 2).

The successful treatment of hematological malignancies with CAR $\mathrm{T}$ cells initiated a new era in cancer immunotherapy. In 2011, a case study of three patients with chronic lymphocytic leukemia (CLL) was reported by Carl June's group at the University of Pennsylvania [16, 17]. The patients were treated with CAR-modified $\mathrm{T}$ cells, which recognized the pan-B cell marker CD19. Two patients had complete responses and one patient showed a partial response. In conjunction with destruction of the tumor cells, normal B cells were also eliminated and the patients developed long-term B cell aplasia. Antitumor responses were associated with inflammatory cytokine release and a remarkable expansion of the CD19 CAR T cells in vivo. The initial success was followed by studies across various centers in the USA, presenting scattered evidence of clinical responses. Recently, four well-designed clinical trials targeting CD19-expressing B cell malignancies were published from the National Cancer Institute, the University of Pennsylvania, and Memorial Sloan Kettering Cancer Center, with very promising results [18-21]. Lee et al. [21] treated 21 patients and reported a complete response rate of $66.7 \%$ (14/21 patients), with only four patients not responding to the treatment. Kochenderfer et al. [20] reported complete responses in 8 out of 15 treated patients. Three patients had partial responses, one patient had disease stabilization, and two patients were not evaluable for response. Maude et al. [18] treated 30 children with acute lymphocytic leukemia (ALL) and had an impressive overall response rate of $90 \%$. Davila et al. [19] reported 16 patients treated with CD19 CAR T cells, with an overall response rate of $88 \%$. In the study by Maude et al. CAR T cells containing the $4-1 \mathrm{BB}$ motif on the CAR for costimulation were used, while the other studies used CD28 as the costimulation motif. Comparative studies are needed to determine which second-generation CAR is most beneficial. It is likely that different CARs should be used in different settings. These data, taken together, strongly indicate that CAR T cell therapy holds great potential for the treatment of CD19-positive refractory B cell malignancies, encouraging development of this method for other tumor types.

\section{Prostate Cancer Immunotherapy}

Prostate cancer is the second most common cancer in men worldwide [22]. Although surgical treatment of localized prostate cancer can be curative, the tumor recurs in lymph nodes and bones in a high proportion of the patients. Current therapy for metastatic prostate cancer is noncurative and includes palliative androgen withdrawal, which leads to hormone-resistant disease typically within months. Immunotherapy provides an important option for the treatment of metastatic prostate cancer, as is evident from phase III studies of sipuleucel-T (an antigen-presenting cell vaccine), showing increased overall survival in hormone- 


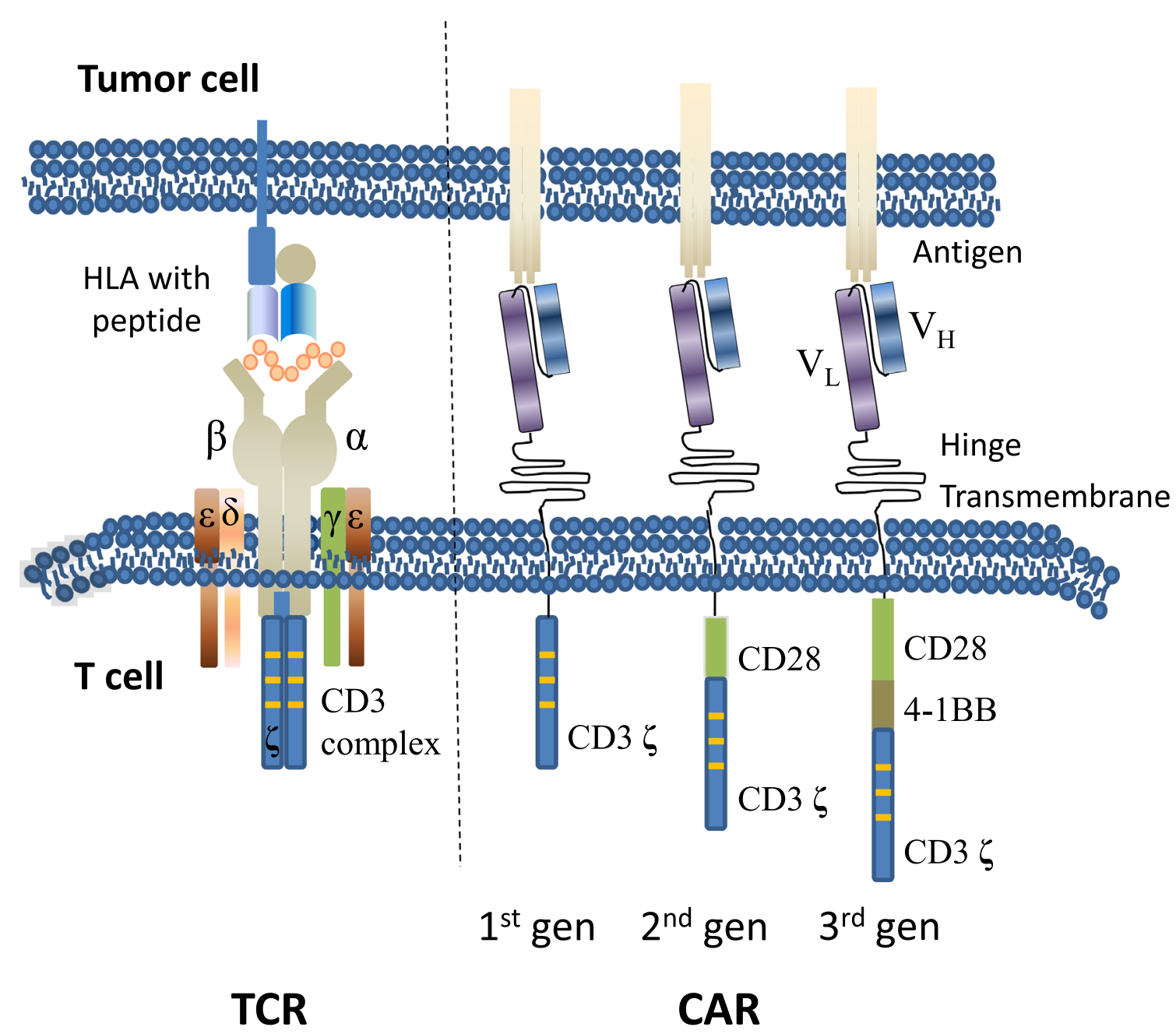

Fig. 1 The structures of a $\mathrm{T}$ cell receptor (TCR) and variousgeneration (gen) chimeric antigen receptors (CARs). The endogenous TCR $\alpha$ and $\beta$ chain complex recognizes an antigenic peptide presented by a human leukocyte antigen (HLA) molecule on target cells. T cell signal transduction is mediated through the $\zeta$ chains of the CD3 complex (the immunoreceptor tyrosine-based activation motifs are depicted in yellow). To build an artificial CAR, an antibody-derived single-chain variable fragment with a light chain $\left(\mathrm{V}_{\mathrm{L}}\right)$ and a heavy chain $\left(\mathrm{V}_{\mathrm{H}}\right)$ is utilized for target recognition. To mimic natural TCR signaling, CARs are engineered with the

refractory prostate cancer patients [23]. Another experimental potentially successful immunotherapy is Prostvac, which constitutes priming with a vaccinia vector encoding prostate-specific antigen (PSA) and three costimulatory molecules [intercellular adhesion molecule (ICAM)-1, lymphocyte function-associated antigen (LFA)3 , and B71-1] followed by a boost with a fowlpox vector [24].

Immune checkpoint blockade antibodies, such as the US Food and Drug Administration (FDA)-approved ipilimumab [a monoclonal anti-cytotoxic T lymphocyte-associated protein (anti-CTLA)-4 antibody] and pembrolizumab [a monoclonal anti-programmed cell death intracellular activation domain of $\mathrm{CD} 3-\zeta$ for signal transduction. For sustained activation, persistence, and improved function, one or several costimulatory domains are added to create so-called secondand third-generation CARs. The most commonly used costimulatory domains are derived from CD28, 4-1BB, OX40, ICOS, and CD27. The costimulatory domains are connected to the extracellular part of the CAR via a transmembrane domain, most commonly derived from CD8 or CD28. To achieve flexibility, a hinge is incorporated in the CAR design

protein (anti-PD)-1 antibody], have shown excellent results in malignant melanoma and multiple other cancers [25]. Therefore, substantial efforts have been made to treat prostate cancer patients with ipilimumab in order to remove inhibition signals for effector $\mathrm{T}$ cells and deplete suppressor regulatory $\mathrm{T}$ cells (Tregs). $\mathrm{T}$ cells infiltrate tumors in the majority of cases of prostate cancer [26], but they have a suppressive Treg phenotype [27-29], express high levels of CTLA-4, and could potentially be sensitive to ipilimumab therapy [30]. Despite initially promising results in early trials [31], a large randomized, doubleblind, phase III study (in 799 patients) showed only a marginal response to ipilimumab in hormone-refractory 
prostate cancer patients who had been treated with radiotherapy [32]. The PD-1/PD ligand 1 (PD-L1) pathway could be important in prostate cancer [33], since PD-1 and PD-L1 have been found to be expressed in TILs obtained from prostate lesions [28, 34]; nevertheless, the few patients who have been treated to date did not respond to the therapy [35, 36]. Checkpoint blockade antibodies may be more beneficial at earlier stages of the disease, and clinical trials are underway to assess their efficacy in patients with a lesser tumor burden.

Monoclonal antibodies directed toward prostate tissuespecific antigens have been used for treatment of prostate cancer. The clinical development has focused mainly on prostate-specific membrane antigen (PSMA) and prostate stem cell antigen (PSCA) as targets [37-39]. PSMA is also expressed in tumor vasculature, which will facilitate targeting of the tumor stroma in addition to tumor cells. Although the anti-PSMA antibody had excellent trafficking to tumors, it failed to induce clinical responses. Thus, monoclonal antibodies targeting tumor-associated antigens may deliver the required specificity but may lack efficacy. It is generally believed that $\mathrm{T}$ cells possess stronger antitumor activity than antibodies because of their remarkable ability to penetrate inflamed epithelial tissues, clonally expand, and generate memory cells. Therefore, to augment the efficacy but keep the specificity of antibody therapy, CAR-modified $\mathrm{T}$ cells directed toward prostate tissuespecific antigens may be a better treatment choice.

\section{CARs for Prostate Cancer: Preclinical Development}

The success of CD19 CAR T cell treatment of B cell malignancies has sparked strong interest in developing CARs for solid tumors as well. As prostate cancer expresses many antigens with limited or no expression in other tissues [40], these tissue-restricted antigens constitute potential targets for CAR T cell therapy. Preclinically, two antigens have been targeted by CARs-namely, PSMA [8, 41-44] and PSCA [44-47]. Early work showed the ability of PSMA CAR T cells to proliferate and recognize PSMApositive targets both in vitro and in animal models [48, 49].

Morgenroth et al. [46] used a first-generation CAR against PSCA to target prostate cancer cells, using a highaffinity receptor generated through immunization of mice. The affinity of different potential antibodies for generation of the CAR was evaluated by flow cytometry. Using the best binding antibody, 7F5, they were able to show expression of the CAR in $\mathrm{T}$ cell lines and immunoreceptor tyrosine-based activation motif (ITAM) phosphorylation of the CD3- $\zeta$ chain. We [45] and Abate-Daga et al. [47] have both shown delayed tumor growth in mice treated with
PSCA CAR-engineered T cells based on the 1G8 and Ha14.117 antibodies, respectively. Although tumor growth was delayed, the tumor-bearing mice were not cured, making it evident that high in vitro cytotoxicity of T cells may not be enough to translate into similar effects in vivo. Zuccolotto et al. showed that PSMA CAR T cells can eradicate disseminated prostate cancer in vivo [42]. This study also illustrated the importance of animal model selection, as human CAR $\mathrm{T}$ cells survive better in nonobese diabetic (NOD)/severe combined immunodeficiency (SCID) mice than in SCID or $\operatorname{Rag} 2^{-/-} / \gamma \mathrm{c}^{-/-}$mice [42]. Kloss et al. [44] chose to select PSCA as a suboptimal target, introducing a low-affinity CAR against PSCA in combination with a high-affinity CAR against PSMA. They showed efficient killing of cells expressing both antigens, suggesting what may be needed to achieve sustained responses.

Another platform that has been implemented to target $\mathrm{T}$ cells to prostate cancer is the use of bispecific antibodies/diabodies, also known as bispecific $\mathrm{T}$ cell engagers (BITEs), which bind both to CD3 on $\mathrm{T}$ cells and to a surface antigen on tumor cells. This strategy forces activated $\mathrm{T}$ cells to be in close proximity to target cells. Diabodies against PSCA [50-53] and PSMA [52, 54-58] have been developed and used successfully in vitro. Animal experiments using these diabodies showed delayed tumor growth but did not cure the mice. Therefore, use of diabodies as a single therapy may be challenging, as they do not provide the cellular memory that adoptively transferred antigen-specific CAR T cells can.

\section{Targeting CAR T Cells to Prostate Metastases}

Localized prostate cancer is curable by surgery; therefore, this review focuses on metastatic prostate cancer. Metastases of prostate cancer are commonly found in lymph nodes and bones. The microenvironment in the bone metastases poses a considerable challenge for the infiltrating CAR $\mathrm{T}$ cells (see Fig. 2). In particular, bone metastases are associated with aberrant angiogenesis [59]. To establish outgrowth, cancer cells may initiate angiogenesis at the site of metastasis by recruiting bone marrowderived endothelial cells. Although increased tumor angiogenesis provides more vessels for potential trafficking of CAR T cells, the quality of the vessels is typically poor, and $\mathrm{T}$ cells are unable to efficiently infiltrate tumors, possibly because of vascular endothelial growth factor (VEGF) expression [60]. Growth factors implicated in angiogenesis are found at elevated levels in prostate cancer bone metastases compared with primary tumors [61]. VEGF has an important role in establishment and outgrowth of prostate cancer bone metastases, as reviewed by Roberts et al. [62]. Besides facilitating recognition and targeting of 


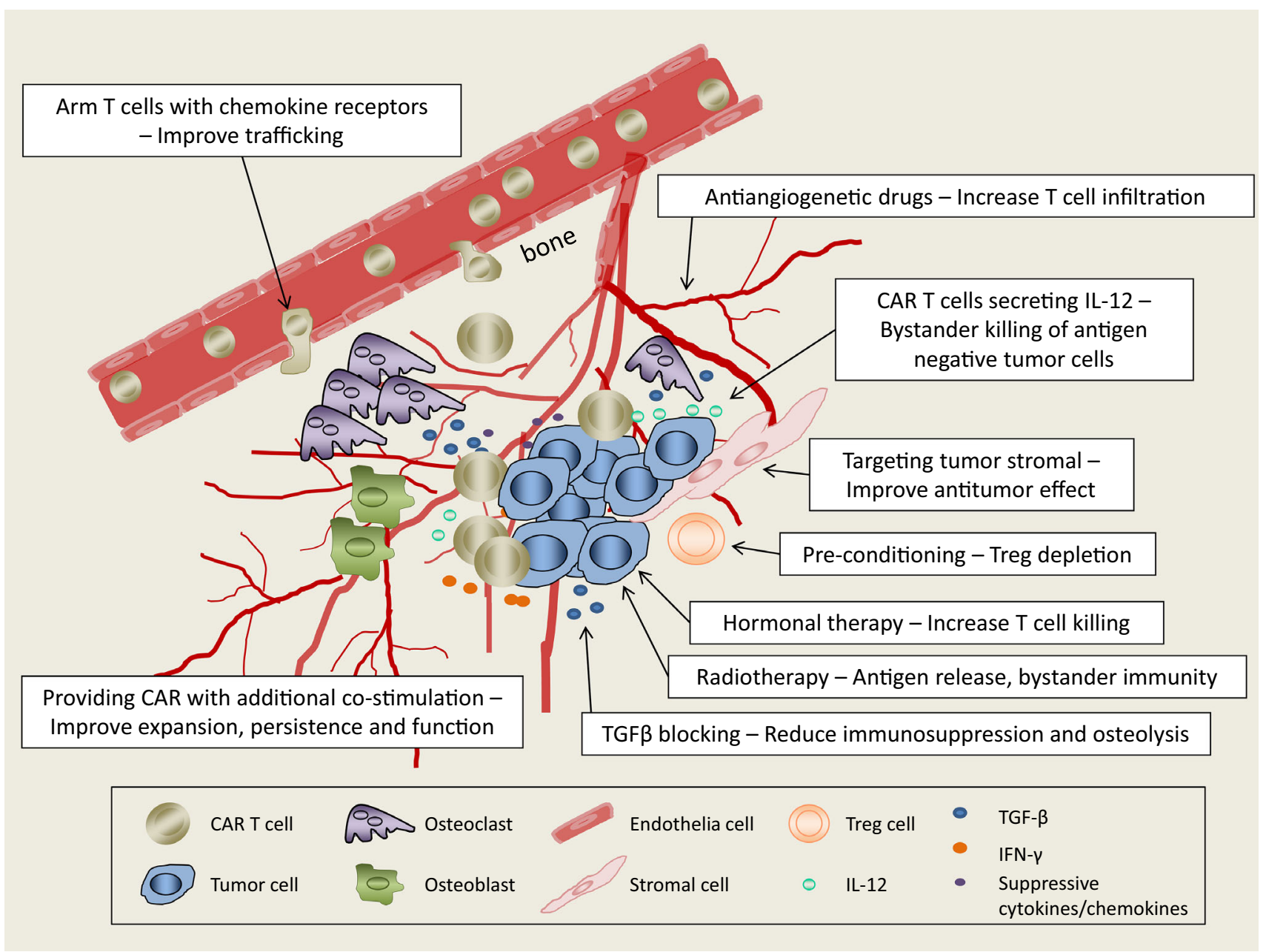

Fig. 2 Illustration of the tumor microenvironment in prostate cancer bone metastases and means of improving chimeric antigen receptor (CAR) $\mathrm{T}$ cell therapy. To achieve trafficking of CAR $\mathrm{T}$ cells to prostate cancer bone metastases, $\mathrm{T}$ cells can be engineered with chemokine receptors to be attracted to factors secreted by tumor cells, tumor stroma, or the bone lesion. T cell infiltration is influenced by blood vessel quality at the metastatic site. Prostate cancer bone metastases have poor vessel quality with dysfunctional junctions. Therefore, treatment with antiangiogenic drugs may normalize the vasculature and improve CAR T cell infiltration. Another approach is to target antigens that are expressed specifically on the tumor vasculature, such as prostate-specific membrane antigen. Tumor cells, as well as fibroblasts and immune cells in the stroma, secrete various immunosuppressive cytokines and chemokines. Osteoclasts at the metastatic site also produce immunosuppressive transforming growth factor (TGF)- $\beta$. The constant activity of osteoblasts and osteoclasts

cancer cells to the bone and establishing new vasculature for tumor growth, VEGF may also affect $\mathrm{T}$ cell infiltration into bone metastases [60]. Improved responses to immunotherapy have been reported with treatment with angiogenesis inhibitors in doses that normalize the vasculature rather than destroying it [63-65]. In the light of these findings, vascular normalization may be important to (which create osteolytic and osteosclerotic lesions, respectively) severely remodels the microenvironment and hinders $\mathrm{T}$ cell function. Blocking osteolysis may help CAR T cell trafficking, and engineering dominant-negative TGF- $\beta$ receptors or signal converter receptors into CAR $\mathrm{T}$ cells may improve their function. To further eliminate the sources of inhibitory cytokines, preconditioning therapy can deplete regulatory $\mathrm{T}$ cells (Tregs) and myeloid-derived suppressor cells. The inclusion of inducible interleukin (IL)-12 in CAR T cells creates a better environment for the $\mathrm{T}$ cells to work in and can activate bystander immunity to kill antigen-negative tumor cells. Radiotherapy induces antigen release and activation of bystander immunity. Androgen deprivation therapy can render tumor cells more sensitive to $\mathrm{T}$ cell killing. Because of the highly immunosuppressive environment, CAR T cells need sufficient costimulation; therefore, thirdgeneration CARs may be preferable. IFN- $\gamma$ interferon- $\gamma$

improve CAR T cell efficacy in bone metastasis. Even when CAR T cells are able to migrate to the metastatic site, infiltration of $\mathrm{T}$ cells into the metastases may be impaired. When treating a metastatic breast cancer patient, Bernhard et al. [66] reported that disseminated cancer cells were targeted efficiently by human epidermal growth factor receptor 2 (Her2)-specific CAR T cells, but solid metastases 
failed to respond, and the tumors progressed. These studies emphasize the critical importance of conditioning the microenvironment for $\mathrm{T}$ cells.

With the aim of improving the access of $\mathrm{T}$ cells to bone metastases, advantage has been taken of various chemokines that are abundant in metastases. In an elegant study, Pinthus et al. used mild irradiation treatment or cyclophosphamide to induce expression of stromal cellderived factor (SDF)-1 in prostate cancer bone metastases [67]. Chemokine (C-X-C motif) ligand (CXCL) 12, also known as SDF-1, is a strong $\mathrm{T}$ cell attractant [68] and improves $\mathrm{T}$ cell rolling on activated endothelial cells [69]. As $\mathrm{T}$ cell adhesion and rolling were affected by VEGF in an experimental model [60], secretion of factors such as SDF-1, together with normalization of vasculature, may improve $\mathrm{T}$ cell infiltration. Migration of $\mathrm{T}$ cells toward a chemokine gradient depends on the phenotype of the $\mathrm{T}$ cell, as naïve, central memory, effector memory, and stemlike memory $\mathrm{T}$ cells (see Box 3 ) express distinct sets of chemokine and homing receptors. Another approach to increasing $T$ cell trafficking to prostate cancer bone metastases is to engineer in a chemokine receptor gene in CAR T cells. CXCL12 is highly expressed in prostate cancer [70], and engineering its ligand molecule, chemokine C-X-C motif receptor (CXCR) 4 into CAR T cells is a step to further ensure that the CAR $T$ cells reach the tumor. More importantly, CXCR4 has implications in metastatic disease, and a recent study found a correlation between its increased expression and metastatic prostate cancer [71]. Similarly, improved trafficking of CAR T cells engineered to co-express chemokine (C-C motif) receptor (CCR) 2 has been achieved by several groups in different tumor models [72-74] and may also prove useful for targeting metastatic prostate cancer. Chemokine (C-C motif) ligand (CCL) 2, the ligand for $\mathrm{CCR} 2$, is vital for growth, metastasis formation, and angiogenesis. Most importantly, however, it regulates bone osteolysis and regulation of osteoclasts in metastatic prostate lesions [75]. Prostate cancer cells secrete various cytokines [76], and trafficking of $\mathrm{CD}^{+}$cells has been improved by introduction of CCR4, which targets several chemokines, including CCL2, CCL4, CCL5, and CCL22 [77]. Co-expression of chemokine receptors and CARs from the same vector expression cassette will most likely result in generation of $\mathrm{T}$ cells with more optimal trafficking to prostate cancer metastases.

Metastatic prostate tumors in the bone microenvironment stimulate bone resorption, resulting in secretion of growth factors, including transforming growth factor (TGF)- $\beta$ [78], which is one of the most suppressive immune inhibitory cytokines. There is evidence that $\mathrm{T}$ cell responses can be improved upon blockade of osteolytic activity, which suggests a role for $\mathrm{T}$ cells as inhibitors of metastatic growth in the bone [79]. Tumors counteract the
$\mathrm{T}$ cell attack by secreting factors that activate osteoclast formation and function, leading to $\mathrm{T}$ cell suppression. Furthermore, some of these factors can differentiate $\mathrm{T}$ cells toward suppressor cells, which in turn favors osteoclast function and tumor progression [80]. A CAR T cell in such an environment may certainly need additional modification to strengthen its responsiveness to tumors.

\section{Improving Resistance of CAR T Cells to Immunosuppression}

TGF- $\beta$ suppresses CD8 ${ }^{+}$effector T cells and is capable of modulating the $\mathrm{CD}^{+}$helper $\mathrm{T}$ cell phenotype toward a Treg. Therapies aimed at blocking TGF- $\beta$ can be administered in combination with CAR T cells engineered to counteract the suppressive tumor microenvironment. One way to counteract the effect of TGF- $\beta$-induced repression of $\mathrm{T}$ cell proliferation is inclusion of CD28 costimulatory domains in the CAR design [81]. Another way is to introduce a dominant-negative TGF- $\beta$ receptor in the CAR T cells [82]. Studies in the pmel melanoma mouse model [83] show improved antitumor activity of TCR-specific T cells modified to be resistant to effects of TGF- $\beta$ [84]. Sustained costimulation may also be crucial for effective responses. A CAR with CD28 and OX40 costimulatory domains rescued $\mathrm{CCR} 7^{-}$-redirected $\mathrm{T}$ cells from activation-induced cell death, and they performed better than $\mathrm{CCR} 7^{+}$-redirected $\mathrm{T}$ cells in terms of the antitumor response [85], possibly because of the ability of OX40 and CD28 to induce Bcl-2 and Bcl-XL expression and establish memory T cells [86]. The clinical relevance of costimulation is evident from successful clinical trials employing artificial antigen-presenting cells to stimulate $\mathrm{T}$ cells [87], and positive correlation of $\mathrm{CD} 27$ and $\mathrm{CD} 28$ expression with telomere length and tumor regression in TIL therapy [88].

To further counteract the immunosuppressive tumor milieu, improve $\mathrm{T}$ cell function, and shift the $\mathrm{T}$ cell response toward a $\mathrm{T}$ helper- 1 type, CAR $\mathrm{T}$ cells engineered to secrete interleukin (IL)-12 or other cytokines have been developed $[89,90]$. Local secretion of IL-12 can recruit other effector immune cells, such as macrophages and neutrophils, to target antigen-negative tumor cells and tumor stroma. Antigen-independent responses following CAR T cell therapy could be at least in part dependent on macrophages. Increased macrophage numbers were seen in the IL-12-secreting CAR T cells in comparison with $\mathrm{T}$ cells engineered with only the CAR molecule, and that led to more efficient tumor eradication and increased tumor necrosis factor (TNF)- $\alpha$ levels [91]. To enhance targeting toward the stroma, one study used a VEGF-directed CAR secreting IL-12 [92]. Another advantage of delivering IL12 at the tumor site is the possibility of minimizing or 
completely avoiding heavy preconditioning of patients prior to CAR T cell infusion [93]. Clinical translation of cytokine-secreting CAR $\mathrm{T}$ cells in hematological malignancies is currently being investigated [94].

An attractive approach to increase the activity of CAR T cells is to combine this therapy with immune checkpoint blockade antibodies. In a transgenic Her2 mouse model, the function of CAR T cells was dramatically enhanced by combination therapy with anti-PD-1 antibody [95]. In addition to increased $\mathrm{T}$ cell function, there was a marked reduction in the number of tumor-infiltrating myeloidderived suppressor cells. Clinical trials of CAR T cells in combination with immune checkpoint blockade antibodies are ongoing.

A relatively new approach is to turn inhibition signals into activating ones. The concept is based on engineering an inhibitory extracellular receptor domain and linking it to a costimulatory intracellular signaling domain. In that way, when a $\mathrm{T}$ cell engages the inhibitory molecule, it will transduce a positive signal instead of a negative signal and become activated. Abundant cell surface inhibitory molecules expressed by tumors, such as CTLA-4 [96] and PD-1 [97], showed encouraging results when this technology was employed. Similarly, engineering of cytokine receptors to transduce positive signaling to $T$ cells upon binding of inhibitory cytokines is another possibility [98].

Selection of a $\mathrm{T}$ cell with known specificity for an antigen that is present in the cancer patient would give physiological stimulation to the CAR $\mathrm{T}$ cell through its native TCR. T cells directed against cytomegalovirus (CMV), Epstein-Barr virus (EBV), and/or adenovirus-all of which are common in the human population and persist in the body - could be used, thereby giving a boost to CAR $\mathrm{T}$ cells via their endogenous TCR. Early clinical results from use of EBV-directed $T$ cells transduced with a CAR directed against the GD2 antigen, which is expressed by neuroblastoma, have been promising and showed increased persistence in comparison with nonspecific GD2 CAR T cells [10]. The results, however, did not translate into significantly prolonged survival in the small group of patients treated so far [99]. The results may also have been attributable to inadequate signaling through the first-generation CAR used in the trial. A new trial using multiviral cospecificity CD19 CAR T cells of the second generation after allogeneic bone marrow transplantation is currently ongoing at Baylor College of Medicine (www. ClinicalTrials.gov study ID NCT00840853).

Recent data suggest that to make prostate cancer cells more susceptible to $\mathrm{T}$ cell killing, androgen deprivation therapy can be used [100]. Tumor-specific $\mathrm{T}$ cells performed better in in vitro killing assays and proliferated more when tumor cells were treated with androgen-inhibitory drugs. The suggested mechanisms are induction of apoptosis by androgen inhibition followed by release of tumor-associated antigens [100] and modulation of $\mathrm{T}$ cell responses through increased helper $\mathrm{T}$ cell differentiation [101]. It should therefore be considered in combination with CAR T cell therapy. Radiotherapy is also a strong inducer of apoptosis and antigen release, and it should therefore also be considered in combination with CAR T cell therapy. Finally, T cell performance in vivo may also depend on how genetically engineered $\mathrm{T}$ cells are expanded in vitro prior to adoptive transfer. Most protocols use antiCD3/CD28 beads or an anti-CD3 antibody together with allogeneic feeder cells to expand $\mathrm{T}$ cells. We have recently shown that if allogeneic dendritic cells are used together with allo-stimulated allogeneic lymphocytes, the expanded genetically engineered $\mathrm{T}$ cells become more resistant to oxidative stress and immunosuppressive cytokines [102].

\section{Clinical Experience of Toxicities Associated with CAR T Cell Therapy}

Treatment of hematological malignancies with CAR T cells is showing impressive clinical responses but also development of severe toxicities. In patients treated with CD19 CAR T cells, cytokine release syndrome, tumor lysis syndrome, and macrophage activation syndrome have been observed [103, 104]. Elevated levels of cytokines such as IL-6, interferon- $\gamma$ (IFN- $\gamma$ ), and TNF- $\alpha$ are observed, which can, in most cases, be managed by use of an anti-IL- 6 receptor antibody (tocilizumab) or corticosteroids. Tocilizumab is suggested to be less toxic to the infused CAR $\mathrm{T}$ cells and is the preferred treatment option to manage side effects [105]. The limited use of CAR T cells to treat solid tumors in clinical practice makes it difficult to predict side effects, which may well be different from those observed in leukemia and lymphoma. The antigen target choice for the CAR T cell to treat solid tumors is of critical importance so as to not deplete vital cells and tissues. Ontarget/off-tumor effects are seen in CD19 CAR T celltreated patients, but it is possible to manage these patients with permanent B cell aplasia by immunoglobulin (Ig) administration. Neurological $[19,20,106]$ and cardiac toxicities $[17,107,108]$ observed in patients treated with CD19 CAR T cells are seemingly off-target toxicities but may be caused by a systemic spread of elevated cytokines resulting from recognition of the CAR target, thus indirectly affecting distant sites. It is likely that these toxicities are related to $\mathrm{T}$ cells, since they have been observed with both various different CD19 CAR constructs and bispecific antibodies.

With the exception of melanoma, where mostly TCRengineered $\mathrm{T}$ cells and TIL therapy have produced impressive results after preconditioning [109], little success 
has been accomplished with engineered $\mathrm{T}$ cells for treatment of other solid tumors. So far, clinical data on solid tumors is available only for use of first-generation CARs, with rather disappointing results [10, 99, 110-113]. It is possible that sustained proliferative immune responses were not generated in those studies. There are planned or ongoing clinical trials of treatments for solid tumors, targeting Her2, carcinoembryonic antigen (CEA), VEGF-R2, epidermal growth factor receptor variant III (EGFRvIII), GD2, and fibroblast activation protein (FAP) with second or third-generation CARs in various solid tumors. One of the trials targeting Her2 contains a dominant-negative receptor for TGF- $\beta$ to further resist tumor suppression. It will be of great interest to see whether the improved CARs, in terms of the costimulation motif, will elicit durable cancer regressions. One colon cancer patient with metastases in multiple organs treated with Her2 third-generation CAR T cells died, which led to discontinuation of that trial [114]. The observed lung toxicity was likely caused by the infusion of a large number of lymphocytes, which were trapped in the lungs, where low expression of the Her2 target antigen led to strong activation of the CAR $\mathrm{T}$ cells due to the additional costimulatory domains incorporated into the CAR design. Although it may be important to have strong signaling and costimulation, the target choice for the development of CAR T cells must be selected with great care. Ideally, mutated or other antigens strictly confined to the tumor would be used. To date, there are no clinical data on the use of CAR T cells for prostate cancer. A study targeting PSMA after cyclophosphamide preconditioning with a second-generation CAR for metastatic prostate cancer is currently recruiting patients at Memorial Sloan Kettering Cancer Center (www.ClinicalTrials.gov study ID NCT01140373).

\section{Improving the Safety of CAR T Cell Therapy}

Use of antigens with prostate-specific expression as targets for CARs to avoid toxicity and targeting of several antigens simultaneously can improve the specificity for tumors (see Box 4). Kloss et al. [44] demonstrated that targeting of one antigen with a CAR of lower affinity can be efficient when $\mathrm{T}$ cells transduced with a second CAR against a second antigen provide costimulation signals. That method could be useful for improving safety in targeting of overexpressed rather than tumor-specific antigens, as the single-transduced $\mathrm{T}$ cells did not elicit significant cytotoxic responses. Two additional reports have focused on dissociated recognition and costimulation. Both attempts described adequate activation of CAR T cells, but Wilkie et al. [115] failed to demonstrate sufficient cytokine release. In contrast, efficient cytokine release and protection of CAR T cells from activation-induced cell death was accomplished with provision of costimulation in trans [116].

An alternative strategy to improve the safety of patients receiving CAR T cell therapy is inclusion of inducible suicide gene cassettes. This strategy allows for rapid eradication of CAR-transduced T cells in cases of adverse events. Initial studies evaluated constitutively expressed herpes simplex virus thymidine kinase (HSV-TK), which, upon nucleoside analog addition, phosphorylates the analogs, followed by incorporation into DNA, which stops DNA synthesis. However, although HSV-TK is effective in dividing cells, it is not effective in nondividing cells, and its viral origin could lead to elimination of CAR T cells because of its immunogenicity. New approaches use inducible caspase systems, the most used being caspase 9 [117], with the caspase being fused to a protein domain that binds the otherwise nontoxic AP1903 drug. Upon binding of AP1903, the dimerization domains are brought together, which leads to dimerization of caspase 9 and subsequent cleavage of the executive caspase 3. Successful use of caspase 9 as a suicide gene in clinical practice has already been reported [118].

CAR-transduced $\alpha \beta$ T cells still bear their endogenous TCR and thus have an additional and often unknown specificity. To avoid potential toxicity, the endogenous TCR can be knocked down with short-hairpin RNA (shRNA) or completely knocked out with zinc finger or transcription activator-like effector nucleases (TALENs) or with CRISPR/Cas9 technology [119-121]. To universalize CAR treatment and extend the activity of CAR $\mathrm{T}$ cells toward any tumor target, anti-fluorescein isothiocyanate (anti-FITC) CAR T cells targeting FITC-tagged tumor cellselective antibodies have been developed [122]. Moving toward "off the shelf" therapies, pioneering work aims to use adoptive transfer of allogeneic $\mathrm{T}$ cells, engrafted with a tumor-specific CAR and where expression the of endogenous TCR has been disrupted [119]. Alternatively, the CAR molecule could be introduced in $\gamma \delta \mathrm{T}$ cells [123] or natural killer (NK) cells [124], which are also highly cytolytic killer cells but lack an endogenous $\alpha \beta$ TCR.

\section{Conclusions}

CAR $\mathrm{T}$ cell therapy for prostate cancer holds promise, given that measures are taken to overcome the highly suppressive tumor microenvironment and to improve the trafficking of T cells toward bone metastases. Strong costimulation signals leading to $\mathrm{T}$ cell persistence may be important to obtain long-lasting sustained tumor regression. It is currently unknown whether a second-generation CAR may provide strong enough costimulation for $\mathrm{T}$ cells in the highly immunosuppressive prostate metastasis lesions. Introducing "signal-converted" receptors in order to 
provide positive stimulation upon binding of inhibitory molecules may further render the CAR T cells resistant to suppression. To keep the CAR T cells activated, local secretion of IL-12 could provide a T helper- 1 stimulus to the $\mathrm{T}$ cells and ensure a beneficial milieu for them to function. Additionally, IL-12 secretion may mediate destruction of antigen-negative tumor cells through bystander immune responses. To further enhance bystander immunity, a combination therapy with oncolytic viruses, immune stimulatory molecules, or irradiation therapy, which will induce antigen release, are good options. Silencing inhibitory molecules, such as Fas, or targeting prostate tumors with CAR $\mathrm{T}$ cells in combination with checkpoint blockade antibodies, such as anti-CTLA4, anti-PD-1, and/ or anti-PD-L1, may lead to synergistic effects and strengthen the immune response mounted by the CAR T cells. As the CAR T cells are likely to face a harsh microenvironment in the tumors and, in particular, large amounts of TGF- $\beta$, which are typical for prostate cancer bone metastases, dominant-negative inhibitory receptors could be utilized. The fitness of the $\mathrm{T}$ cells when they are infused is crucial, and adoptively transferred $\mathrm{T}$ cells should be resistant to exhaustion. To achieve this, minimally cultured $\mathrm{T}$ cells, stem-like $\mathrm{T}$ cells, or central memory $\mathrm{T}$ cells could be selected. To improve trafficking of $\mathrm{T}$ cells to metastases, which is a major hurdle, chemokine receptors such as CCR2 may be co-expressed in the CAR T cells. Angiogenesis inhibitor drugs may be useful to improve CAR T cell infiltration into the tumor tissue. CAR T cells targeting the tumor vasculature is another option. Carefully choosing the target antigen is of outmost importance, and safety measures such as inclusion of suicide gene cassettes must be undertaken to avoid toxicity. Additionally, double specificities or dissociated signaling domains may be used to further improve safety.

Acknowledgments The Swedish Cancer Society and Gunnar Nilsson's Cancer Foundation supported this work. The authors have no conflicting financial interests.

Open Access This article is distributed under the terms of the Creative Commons Attribution-NonCommercial 4.0 International License (http://creativecommons.org/licenses/by-nc/4.0/), which permits any noncommercial use, distribution, and reproduction in any medium, provided the original author(s) and the source are credited.

\section{Box 1: Chimeric Antigen Receptor (CAR) Design: The Building Blocks}

Extracellular domain for target recognition: Most commonly, the extracellular domain of a CAR is a single-chain variable fragment of a monoclonal antibody with high affinity for an antigen expressed on the surface of tumor cells.
While comparing CARs directed at the receptor tyrosine kinase-like orphan receptor 1 (ROR1) antigen that had a 50-fold difference in affinity, Riddell's group showed superior function on the part of the higher-affinity CAR T cells, which were also protected from activation-induced cell death [125]. However, increasing the affinity beyond a certain threshold may not improve the efficacy of the treatment, as a plateau of the response is reached [126-128].

Hinge region: Although it does not affect the specificity, the hinge or spacer region is important for CAR T cell function. An inappropriate length of the hinge can cause loss of function. In an experiment comparing long, short, and intermediate hinges of a CAR against ROR1, the shorthinge CAR T cells mediated the most efficient response in terms of T cell killing and cytokine release, followed by the intermediate-hinge cells and the long-hinge cells [125]. The mechanism may be that the immunoglobulin (Ig) G4 $\mathrm{CH} 2-\mathrm{CH} 3$ fragment crystallizable $(\mathrm{Fc})$ spacer interacts with myeloid cells, and CAR $\mathrm{T}$ cells die as a result of activation-induced cell death, as mutating the Fc receptor binding site restores their functionality and persistence in vivo [129]. The IgG1 CH2-CH3 hinge, which is commonly used, may elicit innate immune responses that could lead to elimination of CAR T cells, and modification may be required to avoid immune recognition [130]. The optimal length of the hinge could be dependent on the antigen that is targeted, as was evident from the study by Guest et al. [131], which inserted a hinge into hingeless CARs against different antigens. The hinge enhanced the functions of CARs against certain antigens while decreasing the functions of other CARs. More research is needed to elucidate the mechanisms underlying CAR construction and to tailor the hinge length to the antigen of interest.

Transmembrane and intracellular domains: To connect the extracellular parts of the CAR to the signaling and costimulatory intracellular domains, CD3- $\zeta, \mathrm{CD} 4, \mathrm{CD} 8$, and CD28 transmembrane domains have been used. For CARs bearing the $\mathrm{CD} 3-\zeta$ transmembrane domain, association with endogenous $\mathrm{T}$ cell receptor complexes increases function [132]. Intracellular domains most often contain the CD3- $\zeta$ chain with immunoreceptor tyrosinebased activation motifs for signaling and often costimulation domains derived from one or more of CD28, 4-1BB, CD27, ICOS, or OX40. The importance of costimulation is discussed in more detail in Sect. 5.

\section{Box 2: Systems for Chimeric Antigen Receptor (CAR) Gene Transfer into T Cells}

Retroviral and lentiviral vectors: These vectors are currently the most commonly used vectors for transfer of CARs into $T$ cells [133]. It is possible to achieve high and 
long-lasting CAR expression upon retroviral transduction of proliferating $\mathrm{T}$ cells. Although the use of a retroviral vector has induced insertional mutagenesis in hematopoietic stem cells and led to the development of leukemia [134], such an effect has not been observed in fully differentiated $\mathrm{T}$ cells. Lentiviral vectors may be advantageous, since they do not require dividing cells, which could be beneficial in generation of stem-like or young $\mathrm{T}$ cells. Although lentiviral gene transfer to quiescent cells is efficient for some cell types, the process is inefficient in inactivated T cells; the reason may be lack of low-densitylipoprotein receptors on T cells [135], which is required for vesicular stomatitis virus glycoprotein (VSV-G)-pseudotyped lentivirus cell entry. A measles virus glycoproteinpseudotyped lentiviral vector has been suggested as an alternative [136].

Nonviral gene transfer: For treatment with new CARs with unknown toxicity, persistence of CAR T cells may be detrimental. One way to avoid this is to transiently express the CAR in $\mathrm{T}$ cells-for example, by using transfected in vitro-transcribed messenger RNA (mRNA). The method can be scaled up for large volumes and applied in clinical practice [137]. Since expression is not durable, repeated mRNA-transfected CAR T cell infusions are needed. In one small study, a patient developed anaphylactic shock after the third infusion of mRNA-transfected mesothelin CAR T cells [108], while in another small study from the same laboratory, toxicity was not observed [138]. The use of mRNA to transfer genes into $\mathrm{T}$ cells gives the advantage of high gene expression, and robust transfection protocols have been generated [139]. Other nonviral systems translated into clinical practice include transposons such as Sleeping Beauty and PiggyBac. Initial reports showing stable gene transfer into T cells were reported in 2006 by Huang et al. [140], followed by introduction of CAR genes into $\mathrm{T}$ cells by use of that system in 2008 [141, 142]. Sleeping Beauty-modified T cells expressing anti-CD19 CARs have been used to treat patients with advanced leukemia [87].

\section{Box 3: The T Cell Subset of Choice for Generation of Chimeric Antigen Receptor (CAR) T Cells}

To date, most clinical trials have used unfractionated $\mathrm{T}$ cells containing both $\mathrm{CD} 8^{+}$and $\mathrm{CD} 4^{+} \mathrm{T}$ cells. $\mathrm{CD} 8^{+} \mathrm{T}$ cells are the classical cytolytic $\mathrm{T}$ cells, but, as both subsets can be activated through CARs, $\mathrm{CD} 4^{+}$helper CAR T cells may be beneficial for expansion and function of $\mathrm{CD}^{+}$ effector CAR T cells [143]. However, the optimal ratio between $\mathrm{CD} 8^{+}$and $\mathrm{CD} 4^{+} \mathrm{T}$ cells has yet to be determined.

It is currently not known what the optimal functional specialization of the $\mathrm{T}$ cells to be transferred is. By using seminal adoptive transfer experiments in primates, Riddell and colleagues showed increased persistence of central memory $\mathrm{T}$ cells $(\mathrm{Tcm})$ compared with effector memory $\mathrm{T}$ cells (Tem) [144]. In a study by Restifo and colleagues, using the pmel mouse model, naïve $\mathrm{T}$ cells were reported to have antitumor activity superior to that of Tcm [145]. Recently, Restifo's group reported on a human memory $\mathrm{T}$ cell subset with stem-like properties, referred to as stem cell memory $\mathrm{T}$ cells $(\mathrm{Tscm})$, with enhanced capacity for self-renewal and a multipotent ability to derive central memory, effector memory, and effector T cells. [146]. In particular, the Tscm subset expressing $\mathrm{CD}_{2} \mathrm{~L}^{\text {hi }}$ is suggested to have very high proliferative capacity combined with greatly increased persistence in vivo [147]. CAR $\mathrm{T}$ cells of various phenotypes need to be compared side by side before any firm conclusion can be drawn.

\section{Box 4: Target Antigens for Chimeric Antigen Receptor (CAR) T Cells}

Overexpressed tumor-associated antigens: Many CARs are directed toward antigens expressed not only on tumor cells but also on some normal cells-although, in many cases, to a lesser degree. In prostate cancer, prostate stem cell antigen (PSCA) represents an overexpressed antigen with expression correlated to tumor aggressiveness. Preclinical targeting of PSCA has been reported, but expression in normal tissue may limit its use, for toxicity reasons. Two other targets that are overexpressed in prostate cancer are mucin-1 and epithelial cell adhesion molecule (EpCAM). A recent preclinical study with an EpCAM CAR showed promising results, with inhibition of prostate cancer growth and inhibition of metastasis formation [148]. CAR T cells directed against mucin-1 showed an improved effect in combination with antiandrogen therapy [149].

Mutated tumor antigens: Mutated antigens specifically found in cancer cells represent the ideal target for CAR $\mathrm{T}$ cell therapy. The extensive exon-based sequencing of tumors to identify mutations has opened up the possibility of individualized $\mathrm{T}$ cell receptor (TCR) $\mathrm{T}$ cell therapy targeting neo-antigens [150]. Furthermore, $\mathrm{T}$ cell responses against tumor-specific neoantigen epitopes were revealed in patients responding to ipilimumab treatment [151]. That technology may open the door to finding new antigens for TCR-based adoptive immunotherapy, and the approach can be extended to CARs, given that the mutation is large enough to give a targetable structural difference.

Tissue-specific antigens in prostate cancer: The most limiting factor for CAR treatment is the required localization of the antigen to the cell surface. Some major prostate antigens, such as prostate-specific antigen (PSA) and prostatic acid phosphatase (PAP), are unfortunately inaccessible for CAR $\mathrm{T}$ targeting because they are both secreted by the 
prostate. Prostate-specific membrane antigen (PSMA) is thought to be a good target, although initial findings by Murphy and colleagues, who reported an almost prostateexclusive expression [152], underestimated PSMA expression in other normal tissue. More recent studies have revealed weak expression in multiple organs, including the urinary bladder, proximal tubules of the kidney, liver, esophagus, stomach, small intestine, colon, and breast, as well as the ovary stroma [153]. Interestingly, PSMA is highly expressed in tumor vasculature but not in normal vasculature (with the exception of the ovary stroma), thereby presenting an interesting general antitumor target. A clinical trial using CAR T cells targeting PSMA for prostate cancer is ongoing. Other potential PSAs include POTE [154], androgen receptor [155] and transmembrane AMPA receptor regulatory protein (TARP) peptide/human leukocyte antigen (HLA)A2 complexes [156]. Prostate cancer offers a variety of tissue-specific antigens, and while targeting a single antigen may elicit tumor escape, simultaneous targeting of several antigens may be beneficial. It is crucial that the selected target is highly expressed both in the primary tumor and in metastases, and that it is required for tumor growth so that antigen loss will be avoided.

\section{References}

1. Rosenberg SA, Packard BS, Aebersold PM, Solomon D, Topalian SL, Toy ST, et al. Use of tumor-infiltrating lymphocytes and interleukin-2 in the immunotherapy of patients with metastatic melanoma-a preliminary report. New Engl J Med. 1988;319(25):1676-80.

2. Dudley ME, Wunderlich JR, Yang JC, Sherry RM, Topalian SL, Restifo NP, et al. Adoptive cell transfer therapy following nonmyeloablative but lymphodepleting chemotherapy for the treatment of patients with refractory metastatic melanoma. J Clin Oncol. 2005;23(10):2346-57.

3. Morgan RA, Dudley ME, Wunderlich JR, Hughes MS, Yang JC, Sherry RM, et al. Cancer regression in patients after transfer of genetically engineered lymphocytes. Science. 2006;314(5796):126-9.

4. Robbins PF, Kassim SH, Tran TL, Crystal JS, Morgan RA, Feldman SA, et al. A pilot trial using lymphocytes genetically engineered with an NY-ESO-1-reactive T-cell receptor: longterm follow-up and correlates with response. Clin Cancer Res. 2015;21(5):1019-27.

5. Robbins PF, Morgan RA, Feldman SA, Yang JC, Sherry RM, Dudley ME, et al. Tumor regression in patients with metastatic synovial cell sarcoma and melanoma using genetically engineered lymphocytes reactive with NY-ESO-1. J Clin Oncol. 2011;29(7):917-24.

6. Essand M, Loskog ASI. Genetically engineered T cells for the treatment of cancer. J Intern Med. 2013;273(2):166-81.

7. Savoldo B, Ramos CA, Liu E, Mims MP, Keating MJ, Carrum $\mathrm{G}$, et al. CD28 costimulation improves expansion and persistence of chimeric antigen receptor-modified $\mathrm{T}$ cells in lymphoma patients. J Clin Invest. 2011;121(5):1822-6.

8. Zhong XS, Matsushita M, Plotkin J, Riviere I, Sadelain M. Chimeric antigen receptors combining $4-1 \mathrm{BB}$ and CD28 signaling domains augment PI3kinase/AKT/Bcl-XL activation and CD8+ T cell-mediated tumor eradication. Mol Ther. 2010;18(2):413-20.

9. Tammana S, Huang X, Wong M, Milone MC, Ma L, Levine BL, et al. 4-1BB and $\mathrm{CD} 28$ signaling plays a synergistic role in redirecting umbilical cord blood $\mathrm{T}$ cells against $\mathrm{B}$-cell malignancies. Hum Gene Ther. 2010;21(1):75-86.

10. Pule MA, Savoldo B, Myers GD, Rossig C, Russell HV, Dotti $\mathrm{G}$, et al. Virus-specific T cells engineered to coexpress tumorspecific receptors: persistence and antitumor activity in individuals with neuroblastoma. Nat Med. 2008;14(11):1264-70.

11. Carpenito C, Milone MC, Hassan R, Simonet JC, Lakhal M, Suhoski MM, et al. Control of large, established tumor xenografts with genetically retargeted human T cells containing CD28 and CD137 domains. Proc Natl Acad Sci. 2009;106(9):3360-5.

12. Milone MC, Fish JD, Carpenito C, Carroll RG, Binder GK, Teachey D, et al. Chimeric receptors containing CD137 signal transduction domains mediate enhanced survival of $\mathrm{T}$ cells and increased antileukemic efficacy in vivo. Mol Ther. 2009;17(8):1453-64.

13. Wang J, Jensen M, Lin Y, Sui X, Chen E, Lindgren CG, et al. Optimizing adoptive polyclonal $\mathrm{T}$ cell immunotherapy of lymphomas, using a chimeric T cell receptor possessing CD28 and CD137 costimulatory domains. Hum Gene Ther. 2007;18(8):712-25.

14. Zhao YB, Wang QJ, Yang SC, Kochenderfer JN, Zheng ZL, Zhong XS, et al. A herceptin-based chimeric antigen receptor with modified signaling domains leads to enhanced survival of transduced $\mathrm{T}$ lymphocytes and antitumor activity. J Immunol. 2009;183(9):5563-74.

15. Till BG, Jensen MC, Wang J, Qian X, Gopal AK, Maloney DG, et al. CD20-specific adoptive immunotherapy for lymphoma using a chimeric antigen receptor with both CD28 and 4-1BB domains: pilot clinical trial results. Blood. 2012;119(17):3940-50.

16. Porter DL, Levine BL, Kalos M, Bagg A, June CH. Chimeric antigen receptor-modified $\mathrm{T}$ cells in chronic lymphoid leukemia. N Engl J Med. 2011;365(8):725-33.

17. Kalos M, Levine BL, Porter DL, Katz S, Grupp SA, Bagg A, et al. $T$ cells with chimeric antigen receptors have potent antitumor effects and can establish memory in patients with advanced leukemia. Sci Transl Med. 2011;3(95):95ra73.

18. Maude SL, Frey N, Shaw PA, Aplenc R, Barrett DM, Bunin NJ, et al. Chimeric antigen receptor $\mathrm{T}$ cells for sustained remissions in leukemia. N Engl J Med. 2014;371(16):1507-17.

19. Davila ML, Riviere I, Wang X, Bartido S, Park J, Curran K, et al. Efficacy and toxicity management of $19-28 \mathrm{z}$ CAR $\mathrm{T}$ cell therapy in B cell acute lymphoblastic leukemia. Sci Transl Med. 2014;6(224):224ra25.

20. Kochenderfer JN, Dudley ME, Kassim SH, Somerville RP, Carpenter RO, Stetler-Stevenson M, et al. Chemotherapy-refractory diffuse large B-cell lymphoma and indolent b-cell malignancies can be effectively treated with autologous $\mathrm{T}$ cells expressing an anti-CD19 chimeric antigen receptor. J Clin Oncol. 2015;33(6):540-9.

21. Lee DW, Kochenderfer JN, Stetler-Stevenson M, Cui YK, Delbrook C, Feldman SA, et al. T cells expressing CD19 chimeric antigen receptors for acute lymphoblastic leukaemia in children and young adults: a phase 1 dose-escalation trial. Lancet. 2015;385(9967):517-28.

22. Jemal A, Bray F, Center MM, Ferlay J, Ward E, Forman D. Global cancer statistics. CA Cancer J Clin. 2011;61(2):69-90.

23. Kantoff PW, Higano CS, Shore ND, Berger ER, Small EJ, Penson DF, et al. Sipuleucel-T immunotherapy for castrationresistant prostate cancer. N Engl J Med. 2010;363(5):411-22.

24. Kantoff PW, Schuetz TJ, Blumenstein BA, Glode LM, Bilhartz DL, Wyand M, et al. Overall survival analysis of a phase II randomized controlled trial of a poxviral-based PSA-targeted immunotherapy in metastatic castration-resistant prostate cancer. J Clin Oncol. 2010;28(7):1099-105. 
25. Pardoll DM. The blockade of immune checkpoints in cancer immunotherapy. Nat Rev Cancer. 2012;12(4):252-64.

26. Sfanos KS, De Marzo AM. Prostate cancer and inflammation: the evidence. Histopathology. 2012;60(1):199-215.

27. Kiniwa Y, Miyahara Y, Wang HY, Peng W, Peng G, Wheeler TM, et al. CD8+ Foxp3+ regulatory T cells mediate immunosuppression in prostate cancer. Clin Cancer Res. 2007;13(23):6947-58.

28. Sfanos KS, Bruno TC, Maris CH, Xu L, Thoburn CJ, DeMarzo AM, et al. Phenotypic analysis of prostate-infiltrating lymphocytes reveals TH17 and Treg skewing. Clin Cancer Res. 2008;14(11):3254-61.

29. Miller AM, Lundberg K, Ozenci V, Banham AH, Hellstrom M, Egevad L, et al. CD4+ CD25 high T cells are enriched in the tumor and peripheral blood of prostate cancer patients. J Immunol. 2006;177(10):7398-405.

30. Peggs KS, Quezada SA, Chambers CA, Korman AJ, Allison JP. Blockade of CTLA-4 on both effector and regulatory $\mathrm{T}$ cell compartments contributes to the antitumor activity of antiCTLA-4 antibodies. J Exp Med. 2009;206(8):1717-25.

31. Slovin SF, Higano CS, Hamid O, Tejwani S, Harzstark A, Alumkal JJ, et al. Ipilimumab alone or in combination with radiotherapy in metastatic castration-resistant prostate cancer: results from an open-label, multicenter phase I/II study. Ann Oncol. 2013;24(7):1813-21.

32. Kwon ED, Drake CG, Scher HI, Fizazi K, Bossi A, van den Eertwegh AJ, et al. Ipilimumab versus placebo after radiotherapy in patients with metastatic castration-resistant prostate cancer that had progressed after docetaxel chemotherapy (CA184-043): a multicentre, randomised, double-blind, phase 3 trial. Lancet Oncol. 2014;15(7):700-12.

33. Tang PA, Heng DY. Programmed death 1 pathway inhibition in metastatic renal cell cancer and prostate cancer. Curr Oncol Rep. 2013;15(2):98-104.

34. Ebelt K, Babaryka G, Frankenberger B, Stief CG, Eisenmenger $\mathrm{W}$, Kirchner T, et al. Prostate cancer lesions are surrounded by FOXP3(+), PD-1(+) and B7-H1(+) lymphocyte clusters. Eur J Cancer. 2009;45(9):1664-72.

35. Topalian SL, Hodi FS, Brahmer JR, Gettinger SN, Smith DC, McDermott DF, et al. Safety, activity, and immune correlates of anti-PD-1 antibody in cancer. $\mathrm{N}$ Engl $\mathrm{J}$ Med. 2012;366(26):2443-54.

36. Brahmer JR, Drake CG, Wollner I, Powderly JD, Picus J, Sharfman WH, et al. Phase I study of single-agent anti-programmed death-1 (MDX-1106) in refractory solid tumors: safety, clinical activity, pharmacodynamics, and immunologic correlates. J Clin Oncol. 2010;28(19):3167-75.

37. Nanus DM, Milowsky MI, Kostakoglu L, Smith-Jones PM, Vallabahajosula S, Goldsmith SJ, et al. Clinical use of monoclonal antibody HuJ591 therapy: targeting prostate specific membrane antigen. J Urol. 2003;170(6 Pt 2):S84-8 (discussion S88-S89).

38. Bander NH, Milowsky MI, Nanus DM, Kostakoglu L, Vallabhajosula S, Goldsmith SJ. Phase I trial of (177)lutetium-labeled J591, a monoclonal antibody to prostate-specific membrane antigen, in patients with androgen-independent prostate cancer. J Clin Oncol. 2005;23(21):4591-601.

39. Olafsen T, Gu Z, Sherman MA, Leyton JV, Witkosky ME, Shively JE, et al. Targeting, imaging, and therapy using a humanized antiprostate stem cell antigen (PSCA) antibody. J Immunother. 2007;30(4):396-405.

40. Essand M. Gene therapy and immunotherapy of prostate cancer: adenoviral-based strategies. Acta Oncol. 2005;44(6):610-27.

41. Santoro SP, Kim S, Motz GT, Alatzoglou D, Li C, Irving M, et al. $\mathrm{T}$ cells bearing a chimeric antigen receptor against prostatespecific membrane antigen mediate vascular disruption and result in tumor regression. Cancer Immunol Res. 2015;3(1):68-84.
42. Zuccolotto G, Fracasso G, Merlo A, Montagner IM, Rondina M, Bobisse S, et al. PSMA-specific CAR-engineered T cells eradicate disseminated prostate cancer in preclinical models. PLoS One. 2014;9(10):e109427.

43. Ma Q, Gomes EM, Lo AS, Junghans RP. Advanced generation anti-prostate specific membrane antigen designer $\mathrm{T}$ cells for prostate cancer immunotherapy. Prostate. 2014;74(3):286-96.

44. Kloss CC, Condomines M, Cartellieri M, Bachmann M, Sadelain M. Combinatorial antigen recognition with balanced signaling promotes selective tumor eradication by engineered T cells. Nat Biotechnol. 2013;31(1):71-5.

45. Hillerdal V, Ramachandran M, Leja J, Essand M. Systemic treatment with CAR-engineered $\mathrm{T}$ cells against PSCA delays subcutaneous tumor growth and prolongs survival of mice. BMC Cancer. 2014;14:30.

46. Morgenroth A, Cartellieri M, Schmitz M, Gunes S, Weigle B, Bachmann M, et al. Targeting of tumor cells expressing the prostate stem cell antigen (PSCA) using genetically engineered T-cells. Prostate. 2007;67(10):1121-31.

47. Abate-Daga D, Lagisetty KH, Tran E, Zheng Z, Gattinoni L, Yu Z, et al. A novel chimeric antigen receptor against prostate stem cell antigen mediates tumor destruction in a humanized mouse model of pancreatic cancer. Hum Gene Ther. 2014;25(12):1003-12.

48. Gade TP, Hassen W, Santos E, Gunset G, Saudemont A, Gong $\mathrm{MC}$, et al. Targeted elimination of prostate cancer by genetically directed human T lymphocytes. Cancer Res. 2005;65(19):9080-8.

49. Maher J, Brentjens RJ, Gunset G, Riviere I, Sadelain M. Human T-lymphocyte cytotoxicity and proliferation directed by a single chimeric TCRzeta/CD28 receptor. Nat Biotechnol. 2002;20(1):70-5.

50. Feldmann A, Stamova S, Bippes CC, Bartsch H, Wehner R, Schmitz M, et al. Retargeting of $T$ cells to prostate stem cell antigen expressing tumor cells: comparison of different antibody formats. Prostate. 2011;71(9):998-1011.

51. Feldmann A, Arndt C, Topfer K, Stamova S, Krone F, Cartellieri $\mathrm{M}$, et al. Novel humanized and highly efficient bispecific antibodies mediate killing of prostate stem cell antigen-expressing tumor cells by CD8+ and CD4+ T cells. J Immunol. 2012;189(6):3249-59.

52. Arndt C, Feldmann A, Koristka S, Cartellieri M, Dimmel M, Ehninger A, et al. Simultaneous targeting of prostate stem cell antigen and prostate-specific membrane antigen improves the killing of prostate cancer cells using a novel modular $\mathrm{T}$ cellretargeting system. Prostate. 2014;74(13):1335-46.

53. Arndt C, Feldmann A, Topfer K, Koristka S, Cartellieri M, Temme A, et al. Redirection of CD4+ and CD8+ T lymphocytes via a novel antibody-based modular targeting system triggers efficient killing of PSCA+ prostate tumor cells. Prostate. 2014;74(13):1347-58.

54. Baum V, Buhler P, Gierschner D, Herchenbach D, Fiala GJ, Schamel WW, et al. Antitumor activities of PSMA $\times \mathrm{CD} 3$ diabodies by redirected T-cell lysis of prostate cancer cells. Immunotherapy. 2013;5(1):27-38.

55. Friedrich M, Raum T, Lutterbuese R, Voelkel M, Deegen P, Rau $\mathrm{D}$, et al. Regression of human prostate cancer xenografts in mice by AMG 212/BAY2010112, a novel PSMA/CD3-bispecific BiTE antibody cross-reactive with non-human primate antigens. Mol Cancer Ther. 2012;11(12):2664-73.

56. Fortmuller K, Alt K, Gierschner D, Wolf $\mathrm{P}$, Baum V, Freudenberg N, et al. Effective targeting of prostate cancer by lymphocytes redirected by a PSMA x CD3 bispecific singlechain diabody. Prostate. 2011;71(6):588-96.

57. Buhler P, Molnar E, Dopfer EP, Wolf P, Gierschner D, Wetterauer $\mathrm{U}$, et al. Target-dependent T-cell activation by coligation with a PSMA $\times$ CD3 diabody induces lysis of prostate cancer cells. J Immunother. 2009;32(6):565-73. 
58. Buhler P, Wolf P, Gierschner D, Schaber I, Katzenwadel A, Schultze-Seemann W, et al. A bispecific diabody directed against prostate-specific membrane antigen and CD3 induces T-cell mediated lysis of prostate cancer cells. Cancer Immunol Immunother. 2008;57(1):43-52.

59. Weidner N, Carroll PR, Flax J, Blumenfeld W, Folkman J. Tumor angiogenesis correlates with metastasis in invasive prostate carcinoma. Am J Pathol. 1993;143(2):401-9.

60. Huang H, Langenkamp E, Georganaki M, Loskog A, Fuchs PF, Dieterich LC, et al. VEGF suppresses T-lymphocyte infiltration in the tumor microenvironment through inhibition of NF- $\mathrm{KB}$ induced endothelial activation. FASEB J. 2015;29(1):227-38.

61. Chen J, De S, Brainard J, Byzova TV. Metastatic properties of prostate cancer cells are controlled by VEGF. Cell Commun Adhes. 2004;11(1):1-11.

62. Roberts E, Cossigny DA, Quan GM. The role of vascular endothelial growth factor in metastatic prostate cancer to the skeleton. Prostate Cancer. 2013;2013:418340.

63. Shi S, Chen L, Huang G. Antiangiogenic therapy improves the antitumor effect of adoptive cell immunotherapy by normalizing tumor vasculature. Med Oncol. 2013;30(4):698.

64. Shi S, Wang R, Chen Y, Song H, Chen L, Huang G. Combining antiangiogenic therapy with adoptive cell immunotherapy exerts better antitumor effects in non-small cell lung cancer models. PLoS One. 2013;8(6):e65757.

65. Huang Y, Yuan J, Righi E, Kamoun WS, Ancukiewicz M, Nezivar $\mathbf{J}$, et al. Vascular normalizing doses of antiangiogenic treatment reprogram the immunosuppressive tumor microenvironment and enhance immunotherapy. Proc Natl Acad Sci. 2012;109(43):17561-6.

66. Bernhard H, Neudorfer J, Gebhard K, Conrad H, Hermann C, Nahrig J, et al. Adoptive transfer of autologous, HER2-specific, cytotoxic T lymphocytes for the treatment of HER2-overexpressing breast cancer. Cancer Immunol Immunother. 2008;57(2):271-80.

67. Pinthus JH, Waks T, Malina V, Kaufman-Francis K, Harmelin A, Aizenberg I, et al. Adoptive immunotherapy of prostate cancer bone lesions using redirected effector lymphocytes. J Clin Invest. 2004;114(12):1774-81.

68. Bleul CC, Fuhlbrigge RC, Casasnovas JM, Aiuti A, Springer TA. A highly efficacious lymphocyte chemoattractant, stromal cell-derived factor 1 (SDF-1). J Exp Med. 1996;184(3):1101-9.

69. Kantele JM, Kurk S, Jutila MA. Effects of continuous exposure to stromal cell-derived factor- 1 alpha on $\mathrm{T}$ cell rolling and tight adhesion to monolayers of activated endothelial cells. J Immunol. 2000;164(10):5035-40.

70. Hirbe AC, Morgan EA, Weilbaecher KN. The CXCR4/SDF-1 chemokine axis: a potential therapeutic target for bone metastases? Curr Pharm Des. 2010;16(11):1284-90.

71. Lee JY, Kang DH, Chung DY, Kwon JK, Lee H, Cho NH, et al. Meta-analysis of the relationship between CXCR4 expression and metastasis in prostate cancer. World $\mathrm{J}$ Mens Health. 2014;32(3):167-75.

72. Asai H, Fujiwara H, An J, Ochi T, Miyazaki Y, Nagai K, et al. Cointroduced functional CCR2 potentiates in vivo anti-lung cancer functionality mediated by $\mathrm{T}$ cells double gene-modified to express WT1-specific T-cell receptor. PLoS One. 2013;8(2):e56820.

73. Moon EK, Carpenito C, Sun J, Wang LC, Kapoor V, Predina J, et al. Expression of a functional CCR2 receptor enhances tumor localization and tumor eradication by retargeted human $\mathrm{T}$ cells expressing a mesothelin-specific chimeric antibody receptor. Clin Cancer Res. 2011;17(14):4719-30.

74. Craddock JA, Lu A, Bear A, Pule M, Brenner MK, Rooney CM, et al. Enhanced tumor trafficking of GD2 chimeric antigen receptor T cells by expression of the chemokine receptor CCR $2 b$. J Immunother. 2010;33(8):780-8.
75. Zhang J, Patel L, Pienta KJ. CC chemokine ligand 2 (CCL2) promotes prostate cancer tumorigenesis and metastasis. Cytokine Growth Factor Rev. 2010;21(1):41-8.

76. Salazar N, Castellan M, Shirodkar SS, Lokeshwar BL. Chemokines and chemokine receptors as promoters of prostate cancer growth and progression. Crit Rev Eukar Gene. 2013;23(1):77-91.

77. Di Stasi A, De Angelis B, Rooney CM, Zhang L, Mahendravada A, Foster AE, et al. T lymphocytes coexpressing CCR4 and a chimeric antigen receptor targeting CD30 have improved homing and antitumor activity in a Hodgkin tumor model. Blood. 2009; 113(25):6392-402.

78. Sato S, Futakuchi M, Ogawa K, Asamoto M, Nakao K, Asai K, et al. Transforming growth factor beta derived from bone matrix promotes cell proliferation of prostate cancer and osteoclast activation-associated osteolysis in the bone microenvironment. Cancer Sci. 2008;99(2):316-23.

79. Faccio R. Immune regulation of the tumor/bone vicious cycle. Ann N Y Acad Sci. 2011;1237:71-8.

80. Roato I. Interaction among cells of bone, immune system, and solid tumors leads to bone metastases. Clin Dev Immunol. 2013;2013:315024.

81. Koehler H, Kofler D, Hombach A, Abken H. CD28 costimulation overcomes transforming growth factor-beta-mediated repression of proliferation of redirected human CD4+ and CD8 + T cells in an antitumor cell attack. Cancer Res. 2007;67(5):2265-73.

82. Bollard CM, Rossig C, Calonge MJ, Huls MH, Wagner HJ, Massague $\mathrm{J}$, et al. Adapting a transforming growth factor betarelated tumor protection strategy to enhance antitumor immunity. Blood. 2002;99(9):3179-87.

83. Klebanoff CA, Gattinoni L, Palmer DC, Muranski P, Ji Y, Hinrichs CS, et al. Determinants of successful CD8+ T-cell adoptive immunotherapy for large established tumors in mice. Clin Cancer Res. 2011;17(16):5343-52.

84. Zhang L, Yu Z, Muranski P, Palmer DC, Restifo NP, Rosenberg $\mathrm{SA}$, et al. Inhibition of TGF-beta signaling in genetically engineered tumor antigen-reactive $\mathrm{T}$ cells significantly enhances tumor treatment efficacy. Gene Ther. 2013;20(5):575-80.

85. Hombach AA, Chmielewski M, Rappl G, Abken H. Adoptive immunotherapy with redirected $\mathrm{T}$ cells produces $\mathrm{CCR} 7(-)$ cells that are trapped in the periphery and benefit from combined CD28OX40 costimulation. Hum Gene Ther. 2013;24(3):259-69.

86. Rogers PR, Song JX, Gramaglia I, Killeen N, Croft M. OX40 promotes Bcl-xL and Bcl-2 expression and is essential for longterm survival of CD4 T cells. Immunity. 2001;15(3):445-55.

87. Kebriaei P, Huls H, Jena B, Munsell M, Jackson R, Lee DA, et al. Infusing CD19-directed T cells to augment disease control in patients undergoing autologous hematopoietic stem-cell transplantation for advanced B-lymphoid malignancies. Hum Gene Ther. 2012;23(5):444-50.

88. Huang J, Khong HT, Dudley ME, El-Gamil M, Li YF, Rosenberg SA, et al. Survival, persistence, and progressive differentiation of adoptively transferred tumor-reactive $\mathrm{T}$ cells associated with tumor regression. J Immunother. 2005;28(3):258-67.

89. Chmielewski M, Abken H. CAR T cells transform to trucks: chimeric antigen receptor-redirected $\mathrm{T}$ cells engineered to deliver inducible IL-12 modulate the tumour stroma to combat cancer. Cancer Immunol Immunother. 2012;61(8):1269-77.

90. Chmielewski M, Hombach AA, Abken H. Of CARs and TRUCKs: chimeric antigen receptor (CAR) T cells engineered with an inducible cytokine to modulate the tumor stroma. Immunol Rev. 2014;257(1):83-90.

91. Chmielewski M, Kopecky C, Hombach AA, Abken H. IL-12 release by engineered $\mathrm{T}$ cells expressing chimeric antigen receptors can effectively muster an antigen-independent macrophage response on tumor cells that have shut down tumor antigen expression. Cancer Res. 2011;71(17):5697-706. 
92. Chinnasamy D, Yu Z, Kerkar SP, Zhang L, Morgan RA, Restifo $\mathrm{NP}$, et al. Local delivery of interleukin-12 using T cells targeting VEGF receptor-2 eradicates multiple vascularized tumors in mice. Clin Cancer Res. 2012;18(6):1672-83.

93. Pegram HJ, Lee JC, Hayman EG, Imperato GH, Tedder TF, Sadelain M, et al. Tumor-targeted T cells modified to secrete IL12 eradicate systemic tumors without need for prior conditioning. Blood. 2012;119(18):4133-41.

94. Pegram HJ, Purdon TJ, van Leeuwen DG, Curran KJ, Giralt SA, Barker JN, et al. IL-12-secreting CD19-targeted cord bloodderived $\mathrm{T}$ cells for the immunotherapy of B-cell acute lymphoblastic leukemia. Leukemia. 2015;29(2):415-22.

95. John LB, Devaud C, Duong CP, Yong CS, Beavis PA, Haynes $\mathrm{NM}$, et al. Anti-PD-1 antibody therapy potently enhances the eradication of established tumors by gene-modified T cells. Clin Cancer Res. 2013;19(20):5636-46.

96. Shin JH, Park HB, Oh YM, Lim DP, Lee JE, Seo HH, et al. Positive conversion of negative signaling of CTLA4 potentiates antitumor efficacy of adoptive T-cell therapy in murine tumor models. Blood. 2012;119(24):5678-87.

97. Ankri C, Cohen CJ. Out of the bitter came forth sweet: activating CD28-dependent co-stimulation via PD-1 ligands. Oncoimmunology. 2014;3(1):e27399.

98. Leen AM, Sukumaran S, Watanabe N, Mohammed S, Keirnan J, Yanagisawa R, et al. Reversal of tumor immune inhibition using a chimeric cytokine receptor. Mol Ther. 2014;22(6):1211-20.

99. Louis CU, Savoldo B, Dotti G, Pule M, Yvon E, Myers GD, et al. Antitumor activity and long-term fate of chimeric antigen receptor-positive $\mathrm{T}$ cells in patients with neuroblastoma. Blood. 2011;118(23):6050-6.

100. Ardiani A, Gameiro SR, Kwilas AR, Donahue RN, Hodge JW. Androgen deprivation therapy sensitizes prostate cancer cells to T-cell killing through androgen receptor dependent modulation of the apoptotic pathway. Oncotarget. 2014;5(19):9335-48.

101. Kissick HT, Sanda MG, Dunn LK, Pellegrini KL, On ST, Noel $\mathrm{JK}$, et al. Androgens alter T-cell immunity by inhibiting T-helper 1 differentiation. Proc Natl Acad Sci. 2014;111(27):9887-92.

102. Jin C, Yu D, Hillerdal V, Wallgren AC, Karlsson-Parra A, Essand M. Allogeneic lymphocyte-licensed DCs expand T cells with improved antitumor activity and resistance to oxidative stress and immunosuppressive factors. Mol Ther Methods Clin Dev. 2014;1:14001. doi:10.1038/mtm.2014.1.

103. Kochenderfer JN, Dudley ME, Carpenter RO, Kassim SH, Rose JJ, Telford WG, et al. Donor-derived CD19-targeted T cells cause regression of malignancy persisting after allogeneic hematopoietic stem cell transplantation. Blood. 2013;122(25):4129-39.

104. Xu XJ, Tang YM. Cytokine release syndrome in cancer immunotherapy with chimeric antigen receptor engineered $\mathrm{T}$ cells. Cancer Lett. 2014;343(2):172-8.

105. Barrett DM, Teachey DT, Grupp SA. Toxicity management for patients receiving novel T-cell engaging therapies. Curr Opin Pediatr. 2014;26(1):43-9.

106. Brentjens RJ, Davila ML, Riviere I, Park J, Wang X, Cowell $\mathrm{LG}$, et al. CD19-targeted T cells rapidly induce molecular remissions in adults with chemotherapy-refractory acute lymphoblastic leukemia. Sci Transl Med. 2013;5(177):177ra38.

107. Kochenderfer JN, Dudley ME, Feldman SA, Wilson WH, Spaner DE, Maric I, et al. B-cell depletion and remissions of malignancy along with cytokine-associated toxicity in a clinical trial of anti-CD19 chimeric-antigen-receptor-transduced $\mathrm{T}$ cells. Blood. 2012;119(12):2709-20.

108. Maus MV, Haas AR, Beatty GL, Albelda SM, Levine BL, Liu $\mathrm{XJ}$, et al. T cells expressing chimeric antigen receptors can cause anaphylaxis in humans. Cancer Immunol Res. 2013;1(1):26-31.
109. Weber JS. At the bedside: adoptive cell therapy for melanomaclinical development. J Leukocyte Biol. 2014;95(6):875-82.

110. Lamers CH, Sleijfer S, Vulto AG, Kruit WH, Kliffen M, Debets $\mathrm{R}$, et al. Treatment of metastatic renal cell carcinoma with autologous T-lymphocytes genetically retargeted against carbonic anhydrase IX: first clinical experience. J Clin Oncol. 2006;24(13):e20-2.

111. Kershaw MH, Westwood JA, Parker LL, Wang G, Eshhar Z, Mavroukakis SA, et al. A phase I study on adoptive immunotherapy using gene-modified $\mathrm{T}$ cells for ovarian cancer. Clin Cancer Res. 2006;12(20 Pt 1):6106-15.

112. Lamers CH, Sleijfer S, van Steenbergen S, van Elzakker P, van Krimpen B, Groot C, et al. Treatment of metastatic renal cell carcinoma with CAIX CAR-engineered T cells: clinical evaluation and management of on-target toxicity. Mol Ther. 2013;21(4):904-12.

113. Park JR, Digiusto DL, Slovak M, Wright C, Naranjo A, Wagner $\mathrm{J}$, et al. Adoptive transfer of chimeric antigen receptor re-directed cytolytic $\mathrm{T}$ lymphocyte clones in patients with neuroblastoma. Mol Ther. 2007;15(4):825-33.

114. Morgan RA, Yang JC, Kitano M, Dudley ME, Laurencot CM, Rosenberg SA. Case report of a serious adverse event following the administration of $T$ cells transduced with a chimeric antigen receptor recognizing ERBB2. Mol Ther. 2010;18(4):843-51.

115. Wilkie S, van Schalkwyk MC, Hobbs S, Davies DM, van der Stegen SJ, Pereira AC, et al. Dual targeting of ErbB2 and MUC1 in breast cancer using chimeric antigen receptors engineered to provide complementary signaling. J Clin Immunol. 2012;32(5):1059-70.

116. Lanitis E, Poussin M, Klattenhoff AW, Song DG, Sandaltzopoulos $\mathrm{R}$, June $\mathrm{CH}$, et al. Chimeric antigen receptor $\mathrm{T}$ cells with dissociated signaling domains exhibit focused antitumor activity with reduced potential for toxicity in vivo. Cancer Immunol Res. 2013;1(1):43-53.

117. Gargett T, Brown MP. The inducible caspase-9 suicide gene system as a "safety switch" to limit on-target, off-tumor toxicities of chimeric antigen receptor T cells. Front Pharmacol. 2014;5:235.

118. Di Stasi A, Tey SK, Dotti G, Fujita Y, Kennedy-Nasser A, Martinez $\mathrm{C}$, et al. Inducible apoptosis as a safety switch for adoptive cell therapy. New Engl J Med. 2011;365(18):1673-83.

119. Torikai H, Reik A, Liu PQ, Zhou Y, Zhang L, Maiti S, et al. A foundation for universal T-cell based immunotherapy: $\mathrm{T}$ cells engineered to express a CD19-specific chimeric-antigen-receptor and eliminate expression of endogenous TCR. Blood. 2012;119(24):5697-705.

120. Berdien B, Mock U, Atanackovic D, Fehse B. TALEN-mediated editing of endogenous T-cell receptors facilitates efficient reprogramming of T lymphocytes by lentiviral gene transfer. Gene Ther. 2014;21(6):539-48.

121. Hsu PD, Lander ES, Zhang F. Development and applications of CRISPR-Cas9 for genome engineering. Cell. 2014;157(6):1262-78.

122. Tamada K, Geng DG, Sakoda Y, Bansal N, Srivastava R, Li ZY, et al. Redirecting gene-modified $\mathrm{T}$ cells toward various cancer types using tagged antibodies. Clin Cancer Res. 2012;18(23):6436-45.

123. Deniger DC, Switzer K, Mi T, Maiti S, Hurton L, Singh H, et al. Bispecific T-cells expressing polyclonal repertoire of endogenous gammadelta T-cell receptors and introduced CD19-specific chimeric antigen receptor. Mol Ther. 2013;21(3):638-47.

124. Klingemann H. Are natural killer cells superior CAR drivers? Oncoimmunology. 2014;3:e28147.

125. Hudecek M, Lupo-Stanghellini MT, Kosasih PL, Sommermeyer D, Jensen MC, Rader C, et al. Receptor affinity and extracellular domain modifications affect tumor recognition by ROR1- 
specific chimeric antigen receptor $\mathrm{T}$ cells. Clin Cancer Res. 2013;19(12):3153-64.

126. Schmid DA, Irving MB, Posevitz V, Hebeisen M, PosevitzFejfar A, Sarria JC, et al. Evidence for a TCR affinity threshold delimiting maximal $\mathrm{CD} 8 \mathrm{~T}$ cell function. $\mathrm{J}$ Immunol. 2010;184(9):4936-46.

127. Dalla Santa S, Merlo A, Bobisse S, Ronconi E, Boldrin D, Milan $\mathrm{G}$, et al. Functional avidity-driven activation-induced cell death shapes CTL immunodominance. J Immunol. 2014;193(9): 4704-11.

128. Zhong S, Malecek K, Johnson LA, Yu Z, Vega-Saenz de Miera E, Darvishian F, et al. T-cell receptor affinity and avidity defines antitumor response and autoimmunity in T-cell immunotherapy. Proc Natl Acad Sci. 2013;110(17):6973-8.

129. Hudecek M, Sommermeyer D, Kosasih PL, Silva-Benedict A, Liu L, Rader C, et al. The non-signaling extracellular spacer domain of chimeric antigen receptors is decisive for in vivo antitumor activity. Cancer Immunol Res. 2015;3(2):125-35.

130. Hombach A, Hombach AA, Abken H. Adoptive immunotherapy with genetically engineered $\mathrm{T}$ cells: modification of the $\mathrm{IgG1} \mathrm{Fc}$ 'spacer' domain in the extracellular moiety of chimeric antigen receptors avoids 'off-target' activation and unintended initiation of an innate immune response. Gene Ther. 2010;17(10): 1206-13.

131. Guest RD, Hawkins RE, Kirillova N, Cheadle EJ, Arnold J, O'Neill A, et al. The role of extracellular spacer regions in the optimal design of chimeric immune receptors-evaluation of four different scFvs and antigens. J Immunother. 2005;28(3): 203-11.

132. Bridgeman JS, Hawkins RE, Bagley S, Blaylock M, Holland M, Gilham DE. The optimal antigen response of chimeric antigen receptors harboring the CD3zeta transmembrane domain is dependent upon incorporation of the receptor into the endogenous TCR/CD3 complex. J Immunol. 2010;184(12):6938-49.

133. Suerth JD, Schambach A, Baum C. Genetic modification of lymphocytes by retrovirus-based vectors. Curr Opin Immunol. 2012;24(5):598-608.

134. Cavazzana-Calvo M, Hacein-Bey S, de Saint Basile G, Gross F, Yvon E, Nusbaum P, et al. Gene therapy of human severe combined immunodeficiency (SCID)-X1 disease. Science. 2000;288(5466):669-72.

135. Amirache F, Levy C, Costa C, Mangeot PE, Torbett BE, Wang CX, et al. Mystery solved: VSV-G-LVs do not allow efficient gene transfer into unstimulated T cells, B cells, and HSCs because they lack the LDL receptor. Blood. 2014;123(9):1422-4.

136. Frecha C, Costa C, Negre D, Gauthier E, Russell SJ, Cosset FL, et al. Stable transduction of quiescent $\mathrm{T}$ cells without induction of cycle progression by a novel lentiviral vector pseudotyped with measles virus glycoproteins. Blood. 2008;112(13): 4843-52.

137. Li L, Allen C, Shivakumar R, Peshwa MV. Large volume flow electroporation of mRNA: clinical scale process. Methods Mol Biol. 2013;969:127-38

138. Beatty GL, Haas AR, Maus MV, Torigian DA, Soulen MC, Plesa G, et al. Mesothelin-specific chimeric antigen receptor mRNA-engineered $\mathrm{T}$ cells induce antitumor activity in solid malignancies. Cancer Immunol Res. 2014;2(2):112-20.

139. Krug C, Wiesinger M, Abken H, Schuler-Thurner B, Schuler G, Dorrie $\mathrm{J}$, et al. A GMP-compliant protocol to expand and transfect cancer patient $\mathrm{T}$ cells with mRNA encoding a tumorspecific chimeric antigen receptor. Cancer Immunol Immun. 2014;63(10):999-1008
140. Huang X, Wilber AC, Bao L, Tuong D, Tolar J, Orchard PJ, et al. Stable gene transfer and expression in human primary $\mathrm{T}$ cells by the Sleeping Beauty transposon system. Blood. 2006;107(2):483-91.

141. Huang X, Guo HF, Kang J, Choi S, Zhou TC, Tammana S, et al. Sleeping Beauty transposon-mediated engineering of human primary $\mathrm{T}$ cells for therapy of $\mathrm{CD} 19(+)$ lymphoid malignancies. Mol Ther. 2008;16(3):580-9.

142. Singh H, Manuri PR, Olivares S, Dara N, Dawson MJ, Huls H, et al. Redirecting specificity of T-cell populations for CD19 using the Sleeping Beauty system. Cancer Res. 2008;68(8):2961-71.

143. Hombach A, Kohler H, Rappl G, Abken H. Human CD4+ $\mathrm{T}$ cells lyse target cells via granzyme/perforin upon circumvention of MHC class II restriction by an antibody-like immunoreceptor. J Immunol. 2006;177(8):5668-75.

144. Berger C, Berger M, Anderson D, Riddell SR. A non-human primate model for analysis of safety, persistence, and function of adoptively transferred T cells. J Med Primatol. 2011;40(2):88-103.

145. Hinrichs CS, Borman ZA, Cassard L, Gattinoni L, Spolski R, Yu $\mathrm{ZY}$, et al. Adoptively transferred effector cells derived from naive rather than central memory $\mathrm{CD} 8(+) \mathrm{T}$ cells mediate superior antitumor immunity. Proc Natl Acad Sci. 2009;106(41):17469-74.

146. Gattinoni L, Lugli E, Ji Y, Pos Z, Paulos CM, Quigley MF, et al. A human memory $\mathrm{T}$ cell subset with stem cell-like properties. Nat Med. 2011;17(10):1290-7.

147. Restifo NP. Big bang theory of stem-like T cells confirmed. Blood. 2014;124(4):476-7.

148. Deng Z, Wu Y, Ma W, Zhang S, Zhang YQ. Adoptive T-cell therapy of prostate cancer targeting the cancer stem cell antigen EpCAM. BMC Immunol. 2015;16(1):1.

149. Sanchez C, Chan R, Bajgain P, Rambally S, Palapattu G, Mims $\mathrm{M}$, et al. Combining T-cell immunotherapy and anti-androgen therapy for prostate cancer. Prostate Cancer Prostatic Dis. 2013;16(2):123-31 (S1).

150. van Buuren MM, Calis JJ, Schumacher TN. High sensitivity of cancer exome-based CD8 $\mathrm{T}$ cell neo-antigen identification. Oncoimmunology. 2014;3:e28836.

151. van Rooij N, van Buuren MM, Philips D, Velds A, Toebes M, Heemskerk B, et al. Tumor exome analysis reveals neoantigenspecific $\mathrm{T}$-cell reactivity in an ipilimumab-responsive melanoma. J Clin Oncol. 2013;31(32):e439-42.

152. Horoszewicz JS, Kawinski E, Murphy GP. Monoclonal antibodies to a new antigenic marker in epithelial prostatic cells and serum of prostatic cancer patients. Anticancer Res. 1987;7(5B):927-35.

153. Silver DA, Pellicer I, Fair WR, Heston WD, Cordon-Cardo C. Prostate-specific membrane antigen expression in normal and malignant human tissues. Clin Cancer Res. 1997;3(1):81-5.

154. Bera TK, Huynh N, Maeda H, Sathyanarayana BK, Lee B, Pastan I. Five POTE paralogs and their splice variants are expressed in human prostate and encode proteins of different lengths. Gene. 2004;4(337):45-53.

155. Olson BM, McNeel DG. Antibody and T-cell responses specific for the androgen receptor in patients with prostate cancer. Prostate. 2007;67(16):1729-39.

156. Epel M, Carmi I, Soueid-Baumgarten S, Oh SK, Bera T, Pastan I, et al. Targeting TARP, a novel breast and prostate tumorassociated antigen, with $\mathrm{T}$ cell receptor-like human recombinant antibodies. Eur J Immunol. 2008;38(6):1706-20. 